\title{
Are policymakers responsive to public demand in climate politics?
}

\author{
Lena Maria Schaffer ${ }^{1 \star}\left(\mathbb{D}\right.$, Bianca Oehl ${ }^{2}$ and Thomas Bernauer ${ }^{2}$ \\ ${ }^{1}$ Universität Luzern Frohburgstrasse 3, 6002 Luzern, Switzerland and ${ }^{2}$ ETH Zürich, Haldeneggsteig 4, 8092 \\ Zürich, Switzerland \\ *Corresponding author. E-mail: lena.schaffer@unilu.ch
}

(Received 17 January 2020; revised 14 April 2021; accepted 5 May 2021; first published online 08 July 2021)

\begin{abstract}
Normative theories of democracy agree that public demand should be the main guide in policymaking. But positive theories and related empirical research disagree about the extent to which this holds true in reality. We address this debate with an empirical focus on climate change policy. Specifically, we are interested in whether observable variation in public demand for climate change mitigation can help explain variation in adopted national climate policies. Using our own data to approximate public demand, we estimate the responsiveness of policymakers to changes in public demand in six OECD countries from 1995 to 2010 . We find that policymakers are responsive and react in predicted ways to variation in our opinion component of measured public demand, rather than to the mere salience of the climate issue. The effect of issue salience is strongest in combination with our opinion measure as this creates a scope for action. The results underscore the importance and usefulness of our concept and empirical measures for public demand, as well as of our disaggregated analysis of climate policy outputs in this area.
\end{abstract}

Key words: climate change policy; comparative politics; issue salience; policy responsiveness; public demand

The global scientific community, as represented through the Intergovernmental Panel on Climate Change (IPCC), has long agreed that anthropogenic causes emissions from the combustion of fossil fuels in particular - are to a large degree responsible for increasing temperatures in many areas of the world and the global average. Nevertheless, designing and implementing appropriate policy responses has turned out to be very difficult. The complexity and unprecedented scale of climate change, the scientific uncertainty that is involved, as well as disagreements over the costs and benefits of reducing greenhouse gas (GHG) emissions have discouraged ambitious policies at the international level (Bernauer 2013).

At the national level, however, policymakers have devoted considerable attention and resources to the issue. Despite this, there is strong variation in the extent to which Annex I countries (advanced industrialised countries that had specific

(c) The Author(s), 2021. Published by Cambridge University Press. This is an Open Access article, distributed under the terms of the Creative Commons Attribution licence (http://creativecommons.org/licenses/by/4.0/), which permits unrestricted re-use, distribution and reproduction, provided the original article is properly cited. 
reduction targets under the Kyoto Protocol) have adopted and implemented domestic climate change mitigation policies (Bernauer and Böhmelt 2013; Burck et al. 2014; see also Victor et al. 2005). Climate policy outputs thus differ between countries with regard to their scope, scale, and timing. Overall, however, scientific evidence (e.g. Masson-Delmotte et al. 2018; UNEP Emissions Gap report 2020) suggests that the climate policies implemented so far will lead to massively overshooting the designated goal of the Paris agreement, which is limiting the global temperature well below $2^{\circ} \mathrm{C}$ compared to preindustrial levels.

Additionally, public awareness of anthropogenic global warming, and particularly of the impacts of climate change and measures needed to mitigate or adapt to its consequences, has steadily increased in many countries since the mid1990s (Lorenzoni and Pidgeon 2006; Stoutenborough et al. 2014; Kachi et al. 2015; Mildenberger et al. 2016, Oehl et al. 2017). Gradually, climate change has moved from a niche issue on the public agenda to one of central concern. The 2019 European Parliament (EP) has been termed as the first climate election in history (Die Zeit 2019; The Guardian 2019), and climate-change-related issues figured more prominently than ever in the 2020 United States (US) election campaign. Overall, in light of the heightened public interest in climate change policy that has been triggered partly by social movements (the Fridays for Future movement, and Extinction Rebellion, etc.) and the observation that countries still need to implement more stringent climate policy to achieve the necessary emissions cuts (UNEP Emissions Gap Report 2020), more knowledge about the public demand and policy output nexus is clearly needed.

In this article, we seek to explain the observed variation in national climate change policy outputs by focusing on domestic demand for climate change mitigation. The reason is that any government's decision about policies for mitigating climate change is ultimately based upon domestic political decisions that are shaped by home-grown electoral preferences, special interests, national discourses, and domestic political institutions (Aklin and Urpelainen 2013). In the case of democracies, conventional wisdom holds that policy choices are, at least to some degree, driven by what the public wants (i.e. public demand). The general presumption here is that democratic policymakers are more attentive and responsive to public demands than their nondemocratic counterparts. The literature offers mixed empirical evidence about whether public demand is in fact, ceteris paribus, a significant determinant of variation in climate policy across countries and over time (Fankhauser et al. 2014).

Our article aims to identify the extent to which differences in public demand for climate change mitigation lead to differences in public policy targeted at GHG mitigation across countries. To this end, we first theoretically distinguish different components of public demand and link them to government responsiveness in climate change policy. A major hindrance to testing the proposed relationship relates to what measures of public demand for climate change mitigation are available and commensurable. As Konisky et al. (2017: 5) rightly point out, "the relationship between societal demand for change and policy outputs under various political institutions remains poorly understood largely because of the lack of empirical material."

Public opinion surveys arguably provide the most direct measure of public demand. However, using such data imposes major limitations on undertaking 
comparative cross-country research over time. In most policy areas, surveys either are not implemented in a large cross-section of countries over long periods of time and/or survey items (in our case, those related to climate change issues) change over time. As Burstein (2010, p. 75) succinctly put it: "It has to be a bad idea to measure public opinion's impact on policy by using whatever survey items are around, however loosely they may be connected to the policy in question." In other words, filling survey data gaps in a meaningful manner ex-post is not possible. ${ }^{1}$

Hence, for the research described herein, we use original data that was handcoded via extensive print media content analysis, as well as new data on legislative activity concerning climate change mitigation in six Annex I countries for the period 1995-2010. We cover the US, Canada, Germany, Switzerland, Italy, and Spain to ensure the representation of different continents (North America and Europe), better- (Germany, Switzerland), and worse climate policy performers (Canada, US) with respect to GHG emissions and climate protection in general, and different levels of exposure to climate-change-related risks. ${ }^{2}$

In our article, we empirically test two different notions of policy responsiveness that take into account the relationship between general demand for climate change policies and the supply of the latter. Our results indeed show that public demand matters for climate change policy adoption. The second notion, target-specific responsiveness, then links demand for different climate policy targets (e.g. policies targeted at the energy supply vis-à-vis policies targeted at buildings) to the supply of policies within these specific domains. While this more detailed analysis exposes our general results to a hard test, it nevertheless confirms the conclusions from our primary analysis about general responsiveness. Both parts of the analysis, but especially the latter part, are highly innovative and - to our knowledge - are novel within the literature on comparative climate change policy in terms of the detail incorporated in both the dependent and independent variables.

The research presented in this article adds to the literature on comparative climate change policy and on policy responsiveness in several important ways. First, we use a more fine-grained concept of public demand for climate change and original data to measure related public demand across countries and time (our independent variable). This is a substantial improvement over other medium-to-large- $\mathrm{N}$ studies in comparative climate change policy, which usually approximate public demand for climate change via votes or numbers of seats for green parties (Holzinger et al. 2008, Hughes and Urpelainen 2015), or via survey data that stems from questions about - for example - the environment, as the most important problem (Bakaki et al. 2020).

\footnotetext{
${ }^{1}$ Recent advances in using multilevel regression and poststratification (MRP) (Lax and Phillips 2009; Caughey and Warshaw 2018) open up new possibilities for estimating public opinion from sparse data. However, given the limited applicability of MRP in cross-country comparative settings (Buttice and Highton 2013; Toshkov 2015) in an issue area with very sparse survey data for some countries (about climate change) dating back to the 1990s, we decided to tread a different path and use media content analysis.

${ }^{2} \mathrm{We}$ had to limit our analysis to six countries because we manually coded data about public demand. As software and dictionaries for automated content analysis are continually improving, this may represent an efficient way to gather data for more countries in the future (Grimmer and Stewart 2013; Loftis and Mortensen 2018).
} 
Second, further merit of our data is that we are able to look at policy responsiveness in relation to subcategories (targets) of climate change policies. This means that we can link target-specific public demand (e.g. claims concerning wind energy promotion) to target-specific policies (e.g. policies on renewable energy). We argue that policy choices between countries vary not only in their absolute number but also to what extent different sectors (targets) are targeted. We thus heed the call of scholars such as Stokes and Breetz (2018) or Schaffer and Levis (2021) for a more disaggregated sectoral analysis of climate policy to eventually be able to theorise on differences between sectoral demand and policy supply. This disaggregation exposes our general responsiveness analysis to a hard test. To our knowledge, this is the first analysis of target-specific responsiveness in comparative environmental politics. Future research may continue in this direction and theorise and analyse differences in responsiveness depending on the sectors targeted in more detail.

Third, with respect to the broader literature on policy responsiveness, we add to existing scholarship by covering a topic of moderate saliency (i.e. climate change). The bulk of studies on responsiveness deal with topics that are highly salient to people (e.g. welfare policy) and research has only recently begun to systematically explore other topics (Lax and Phillips 2012; Vandeweerdt et al. 2016). Scholars such as Burstein $(2003,2006)$ thus note that overall conclusions about the extent of policy responsiveness in democracies may suffer from a confirmatory bias (in the sense of inflated estimates of policy responsiveness) because they are based on items from public opinion surveys that, by design, ask questions about highly salient issues. While we do not have a theoretical explanation for the differences in cross-issue responsiveness, our study, and data collection related to early developments in climate change policy may prove a very useful resource considering that the issue of climate change has increased in saliency from low to high over the past 25 years.

Moreover, we add to the literature by comparing comprehensive climate change policy output for several countries, while most studies on policy responsiveness either rely on public opinion survey data from a single country (Dolšak and Houston 2014; Bromley-Trujillo and Poe 2020) or one component of climate change policy (Anderson et al. 2017).

The remainder of the article is structured as follows. After a brief review of the literature on policy responsiveness in democracies, we outline our theoretical arguments. The subsequent section provides information on the research design and data. We then present the empirical findings and end by discussing their implications for future research and for policymakers.

\section{The responsiveness of democratic policymakers}

Conventional wisdom holds that public demand is an important determinant of public policy choices, particularly in democracies. As noted by Dahl (1971, p. 1), " [a] key characteristic of democracy is the continued responsiveness of the government to the preferences of the people." The logic underlying this presumption is that political leaders that are faced with public demand for or against a particular policy (in the present case, climate change mitigation) have an incentive to satisfy this demand if they wish to remain in office. In democracies, however, citizens do 
not only hold and express their preferences on election day, but they can and do observe their elected government's policy choices and their alignment with their own preferences throughout the electoral cycle.

What ideally happens in democracies corresponds to the notion of dynamic representation, as Stimson et al. (1995, p. 560) define it: "a simple idea and an old one. Public sentiment shifts. Political actors sense the shift. And then they alter their policy behaviour at the margin." Moreover, the concept of "thermostatic representation" proposed by Wlezien (1995) views representation as a dynamic process in which the public and the government respond to one another. As mentioned above, one limitation of prior research about the relationship between mass public opinion and government policy is its geographical concentration on the US, and lack of cross-national comparisons. ${ }^{3}$ Accordingly, within the domain of environmental policy responsiveness, most academic contributions have examined responsiveness in the US states (Ringquist 1994; Hays et al. 1996; Johnson et al. 2005; Agnone 2007; Dolšak and Houston 2014). Hays et al. (1996), for instance, find that US state environmental regulation is "quite responsive" to public opinion. Johnson et al. (2005) use a modified (environmental policy) "thermostatic" model of the reciprocal links between citizen preferences (state-level environmental opinions) and government policy outputs, taking into account the effectiveness of policies. They find a thermostatic adjustment in environmental policy, but only in cases when policy responsiveness has improved environmental conditions. Agnone (2007) examined time series data from the US states in the period 1960-1998 to gauge the impact of the environmental movement on environmental policymaking using public opinion data, as well as data on protests. He found that, when controlling for the saliency-enhancing effect of protests, public opinion influenced changes in pro-environmental public policy. Dolšak and Houston (2014) examined subnational climate change policies in the US. Their method resembles the approach adopted in this article: they used newspaper coverage to explain policy outputs and conclude that legislative activity increased when the consequences of climate change were discussed in the media. In their recent contribution, BromleyTrujilllo and Poe (2020) also link issue salience on climate change and environmental issues to a broad range of climate change policies within US states. They find that variation in salience across states impacts climate policy output. Moreover, various interactions between problem status and issue attention amplify the connection between public issue salience and policy output (Bromley-Trujillo and Poe 2020: 298).

Recent country-comparative contributions by Anderson et al. (2017) and Bakaki et al. (2020) have used survey data from the Eurobarometer to proxy citizens' environmental concerns (Anderson et al. 2017) as well as data on media attention to environmental issues (Bakaki et al. 2020) to explain policy output in the area of energy policy and have found evidence that policymakers react to public demand. Both contributions do not directly test policy responsiveness in the specific area of

\footnotetext{
${ }^{3}$ For example, Burstein's (2003, p. 33) review of past work in the field covers 47 studies on the public opinion and public policy nexus. Of these 47 studies, he notes that "only four pertained to Western Europe, 1 to another developed country and 0 to any developing country or to multiple countries as units of analysis."
} 
climate change as they rely on different environmental questions on, for example, pollution from the Eurobarometer (Anderson et al. 2017: 6; Bakaki et al. 2020: 9) as their public opinion proxy.

In summary, while there is some confirmatory evidence for the public demandpolicy output nexus in environmental policy, research does not yet offer much comparative insight into public demand concerning the issue of climate change. Our contribution can be regarded as the first comparative and comprehensive effort to directly link demand for climate change policies to climate change policy output.

\section{What explains climate policy output?}

We consider policy output (in our study measured by public policy output related to climate change mitigation) to be a function of policymakers' attentiveness to the issue of climate change, related public demand, and the institutional context they operate in.

We thus argue that public policy output tends to occur when policymakers are attentive to a specific issue or problem, and when they feel they need to do something about it in order to respond to public demand (c.f. Shapiro 2011). Our baseline hypothesis is thus simple and straightforward:

Hypothesis:. Stronger public demand for climate change mitigation is likely to lead to more climate policy output. This applies both in aggregate terms, and with respect to the demand for and output of climate policy measures that address specific targets.

The notion that policy responsiveness is present both if we look at the influence of aggregate public demand on aggregate climate change policy output and if we look at target-specific demand and target-specific policy output is central to our study and needs to be explained in greater detail. Policymakers can be responsive and satisfy public demand in different ways. They can - for example - react to the general saliency of an issue or to differences in saliency by increasing public policy output with respect to the issue. We believe this requires a broad definition of governmental issue responsiveness that can help us establish a link between public demand and public policy.

A more specific conceptualisation of government responsiveness to public demand involves looking at public policy output in specific target areas that appear to be dear to the public. To provide a more nuanced view of responsiveness, we will examine both the effect of public demand on the number of climate change mitigation policies adopted per year and country (general responsiveness definition), and the number of climate change mitigation policies adopted with respect to specific targets such as buildings or appliances (specific responsiveness definition) in our empirical analysis. To our knowledge, we are the first to explore target-specific responsiveness in the area of environmental politics. We argue that future comparative research should proceed along this avenue to actually describe and explain climate policy outputs in more detail. Below, we elaborate further on the implications of these two conceptualisations of policy responsiveness and how they relate to our measures of public demand that are described in the following paragraph. 


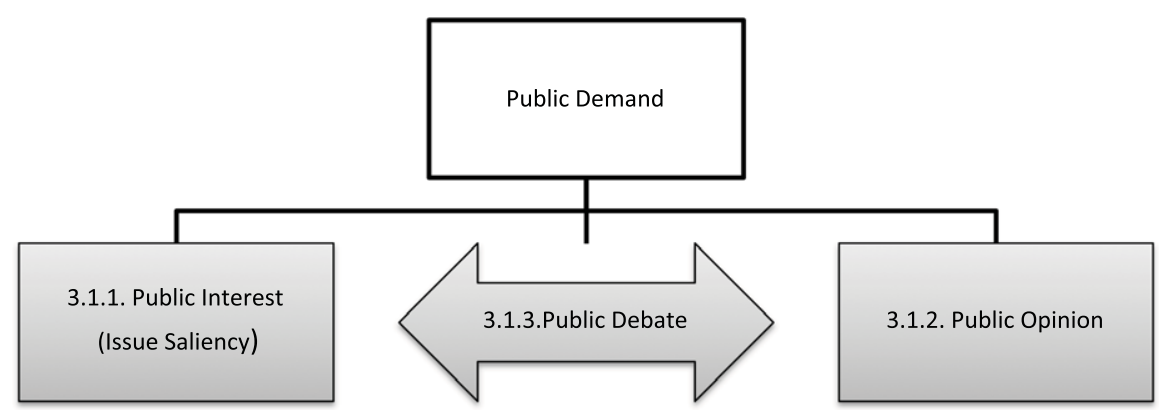

Figure 1. Three dimensions of public demand (c.f. Oehl et al. (2017)).

\section{What is public demand?}

We regard the concept of public demand as consisting of a combination of public interest (issue salience) and public opinion concerning the respective issue (in our case, climate change) (Oehl 2015; Oehl et al. 2017). Figure 1 shows how we conceptualise public demand. The public interest concept (issue salience) captures how important a given issue is from the viewpoint of members of a given social unit (e.g. a country). The opinion concept captures what people think about a given societal problem and, more importantly, what they think should be done about it, if anything, and by whom. The two dimensions are distinct in the sense that individuals may hold opinions about a given issue, whereas the issue may or may not be important (salient) to them. We also argue that the combined effect of the latter (public debate) further enhances policymakers' responsiveness, or more precisely, that higher issue salience increases the impact of opinion on policy responsiveness. We elaborate on this relationship in more detail below.

\section{Public interest (issue saliency)}

Issue salience matters for policy responsiveness because, due to electoral motivations in democracies, policymakers' attentiveness is greater in the case of salient issues. In other words, when policymakers want (and need) to be re-elected, they will turn their attention in policymaking to problems that resonate more strongly with citizens; i.e. salient issues from the public's perspective. Several studies have found that both the public and policymakers tend to prioritise legislation in economic and welfare domains, meaning that responsiveness is relatively high in these areas (Jones and Baumgartner 2005). In relation to the above-mentioned, two implications arise: first, the issue salience of climate change over time is likely to be an influential factor in terms of policy responsiveness in general. We thus expect that greater public interest (issue salience) will be linked with greater legislative activity on climate change.

Second, however, as we have noted above, the attentiveness of policymakers and thus policy outputs are probably generally greater for the key issues on a government's agenda, such as policies dealing with the economy and social welfare (redistribution). This means that we should pay attention to confirmatory bias when studying issues of high salience. Of course, this begs the question of whether climate change is a medium salience issue relative to other issues on the public agenda. We presume that, despite 
recent increases in climate concern, climate change policy is of moderate salience in most countries, especially concerning the 1990s (and relative to other policy issues on national agendas). In most countries, climate-change-related issues do not play a prominent role in processes of electoral competition - at least not yet. Overall, this supports our assertion that climate change is an issue of moderate salience with respect to other national policy issues such as unemployment, welfare, and immigration.

\section{Public opinion}

Another component of public demand that matters for legislative activity is public opinion vis-à-vis the respective issue. In earlier research, public opinion has primarily been measured with survey data. There is a burgeoning literature that seeks to measure and explain individual attitudes towards climate change using survey data (Leiserowitz 2006; McCright and Dunlap 2011; Brulle et al. 2012; Donner and McDaniels 2013; Scruggs and Benegal 2013; Lee et al. 2015), as well as regarding opinion towards different climate policies (Lachapelle et al. 2012; Beiser-McGrath and Bernauer 2019; Douenne and Fabre 2020; Umit and Schaffer 2020; Schaffer 2021). There has been very little work, however, that connects data on public opinion on climate change to climate change policy outputs (Bromley-Trujillo and Poe 2020).

As noted above, the concept of opinion is distinct from salience inasmuch as the former shows people's agreement or disagreement with governmental activity in relation to an issue. ${ }^{4}$ In our case, opinion refers to whether people desire more or less governmental activity in the area of climate change, and the concept is thus more closely linked to public preferences related to public policy than the mere salience of the issue. ${ }^{5}$ Positive opinions about more climate change legislation should thus influence whether policymakers become more attentive, and, as we argue, more active in relation to an issue. Conversely, if public opinion about an issue is negative (less desire for regulation), we expect to observe less public policy output.

\section{Interaction between salience and opinion (public debate)}

While public interest (issue salience) and public opinion are, in our view, the most important single components of issue-specific public demand, we acknowledge that these two components interact, and that issue salience is important in the opinionpolicy responsiveness nexus by enhancing public debate and creating scope for policy action. Our concept of public debate thus brings together both issue salience and issue-related opinion. We submit that, in addition to their direct effects on policy action, the main effect of opinion on responsiveness is contingent on different manifestations of issue salience. Public interest in an issue and stated opinions about an issue may thus mutually enhance policymaking activity as regards creating scope for policy action. The question, however, is which combinations of public interest and public

\footnotetext{
${ }^{4}$ In a survey context, the equivalent would be a generic question targeted at governmental action, thus something along the lines of "Do you think the government is doing enough to combat climate change, or should it do more?" Unfortunately, such a question is not available to sensibly compare countries over time, let alone use to explain public policy output.

${ }^{5}$ For a more detailed discussion of the measurement of public opinion based on news media sources, see Oehl et al. (2017).
} 
Table 1. Expected conditional effect of opinion on different levels of issue salience (scope for action)

\begin{tabular}{lll}
\hline & \multicolumn{2}{c}{ Salience } \\
\cline { 2 - 3 } Opinion & Low & High \\
\hline Negative & Low level of public policy output $(-)$ & No public policy output $(--)$ \\
Neutral & Low level of public policy output & Medium level of public policy output \\
Positive & Medium level of public policy output $(+)$ & High level of public policy output $(++)$ \\
\hline
\end{tabular}

opinion enhance responsiveness, and which combinations tend to dampen policymaking. Does the impact of opinion indeed change as issue salience increases?

We hypothesise that the more salient an issue is, the larger the effect of opinion on policy responsiveness is likely to be (Burstein 2003; Lax and Phillips 2009). In their study on public opinion and policy responsiveness regarding the issue of gay rights, Lax and Phillips (2009) found that the higher the salience of gay rights issues, the greater the policy responsiveness to issue-specific public opinion. We accordingly submit that, from the viewpoint of policymakers, opinion may only matter given that an issue is salient. We propose that the co-occurrence of high levels of issue salience and positive opinion amplifies the direct effect of both on policy output and creates the most favourable conditions for inducing further climate change policies. Our theoretical rationale here is that when the salience of the issue of climate change is high (low) and opinion regarding public policies on climate change is clearly positive (negative), the attentiveness of policymakers will be highest (lowest), as will the related electoral gains (losses) from action (inaction).

Table 1 shows our theoretical expectations concerning the effect of opinion for different levels of salience. This means that we assume that the direction of the effect on policy responsiveness (i.e. whether positive or negative) is determined mainly by whether opinion is positive or negative. Issue salience will then enhance this effect (if high), or diminish it (if low). In considering the level effect of salience, we further expect that positive (negative) changes in salience from one year to another also have the potential to amplify (dampen) the effect of opinion on policy responsiveness.

\section{Partisan preferences}

It is commonly assumed that left-leaning governments pursue greener policies; i.e. that they are more inclined to adopt and implement environmental legislation (Neumayer 2003; Schaffer and Bernauer 2014) and are more responsive in general (Brooks 1985, 1987).

Conversely, right-leaning governments, especially in Anglo-Saxon countries, have been associated with climate scepticism (McCright and Dunlap 2011). Parties on the political left tend to have issue ownership of environmental topics in many countries, and issue ownership has been shown to have a significant impact when an issue is salient (Bélanger and Meguid 2008; Schaffer and Lüth 2021). In general, governments have some capacity to enact legislation during their terms in office and will try to concentrate on legislation that caters to their core constituencies because their aim is to be re-elected. As governments in parliamentary systems have considerable influence to set the agenda within the policymaking process (Tsebelis 2009), left-leaning governments are supposed to introduce more climate 
change legislation. In presidential systems, veto power by the executive makes the partisanship of the government relevant to explain policy choices (Tsebelis 2009), as, for example, the executive branch in the US might veto progressive action on climate change ${ }^{6}$. In any case, it is important to control for the partisanship of the government to explain climate change policy output. And while the effect of partisanship has turned out to be ambiguous in several studies (Ward and Cao 2012; Schaffer and Bernauer 2014), for simplicity we hypothesise that left-leaning governments are more likely to adopt climate change legislation.

\section{Institutional context}

While our main theoretical and empirical contribution focuses on the effects of public demand on climate policy output, we need to control for supply side factors notably, the institutional context. We thus add a brief discussion on the effects of electoral system type, which we regard as a crucial variable.

Electoral system: The type of electoral system may matter for policy responsiveness, but exactly how has been a matter of debate in scholarly research. Powell (2000) finds that majoritarian systems pay greater attention to the ebb and flow of public opinion because a shift in opinion has greater consequences on election day in such systems. Through testing this argument empirically, Wlezien and Soroka (2012) found that governments in proportional systems are less responsive to changing public opinion. However, in terms of government rhetoric, Hobolt and Klemmemsen (2005) find that government is more responsive in Denmark (a proportional system) than in the UK (a majoritarian system).

Institutions are relevant in relation to responsiveness because they change the incentive for policymakers to actually be responsive to the public (Hobolt and Klemmemsen 2005, p. 384). As Fredriksson and Millimet (2004) note, parties in majoritarian electoral systems only need to win the majority of votes in half of all districts, and can therefore strategically focus on (regional) subsets of the population with the electoral platforms they offer. In contrast, in proportional systems, a party has to cater to the preferences of half of the electorate with its platform in order to obtain a majority. Therefore, issues relevant to the entire population should receive more attention from parties in proportional systems. We thus expect that proportional representation is conducive to more legislative activity on climate change.

\section{Data and empirical design \\ Measuring policy output (dependent variable)}

To explain differences in climate change policy output across countries and over time, we need indicators that provide accurate and useful information about laws, regulations, and various other types of public policy measures. ${ }^{7}$ In contrast to other studies that concentrate on a specific subfield of climate policy, such as renewable energy (Matisoff 2008; Schaffer and Bernauer 2014; Anderson et al. 2017), we analyse a rather broad range of policies.

\footnotetext{
${ }^{6} \mathrm{We}$ thank our anonymous reviewer for bringing this up.

${ }^{7} \mathrm{We}$ do not focus on legislation only, but also include governmental activity (e.g. in the US context, executive orders are included) in the area of climate change.
} 
To construct our measure of national climate "policy output", we identified the most important sectors, targets, and instruments used in climate policy. We identified five instruments - taxes, tax incentives, regulations, labels, and subsidies - and four sectors: energy supply, transport, buildings, and appliances and collected data for each country in our sample. With respect to the energy supply and transport sectors, we further distinguished whether a policy targeted renewable energy or fossil fuels (energy supply) or whether it targeted private transport or public transport (transport). For these six targets (renewable energy supply, fossil fuel supply, private transport, public transport, buildings, and appliances), we coded whether in any given year - from 1995 onwards - the country adopted a policy that used a particular instrument and aimed at a particular target (see appendix Figure A.1 for more information). In federal systems, we restricted the measurement to the national level. ${ }^{8}$

We used various information sources, including IEA and EU databases, country reports to the UNFCCC, and information from national environmental and energy agencies to code the data for the dependent variable. Especially useful in this context were the IEA database on Climate Change Policies and Measures (http://www.iea. org/textbase/pm/?mode $=\mathrm{cc}$ ) and the national communications $(\mathrm{NCs})$, which Annex I countries to the Kyoto Protocol submitted under the UNFCCC.

To examine the different conceptualisations of policy responsiveness that are inherent to our main hypothesis, we used two dependent variables. One variable counts the total number of climate policies enacted during a given year (general responsiveness) as a proxy for public policy in the field of climate change. In our sample, the values of this variable range from 0 (=no new policies) to 16 new policies (see Table A.3 in the appendix for summary statistics). Data for this dependent variable also provide us with a policy stock variable [i.e. the cumulated number (sum) of all policy adoptions], which we use as a control variable. Our second dependent variable details the specific targets of policies; for example whether they target appliances or public transport (target-specific responsiveness). It thus also provides information about the total number of climate policies enacted within a specific policy target during a given year.

These two dependent variables implicate two different units of analysis. In the first analysis, which looks at the overall influence of public demand on total climate policy output, the unit of analysis is the country-year. Thus, we analysed one observation per year from the US, Canada, Switzerland, Germany, Italy, and Spain, the six countries in our sample. The second analysis then explored the different policy targets in more detail. Accordingly, the unit of analysis here was the country-year-target. For example, we used one observation per year from the US for the target "renewable energy," one observation from the US for the target "fossil fuels," and so on. All targets were then pooled (Boehmke 2009, pp. 234-235, 242-244). For this target-specific part of the analysis, the independent variables (public demand) were also measured in a target-specific way to provide the same level of detail.

\footnotetext{
${ }^{8}$ Although in some countries - most notably in the US - a significant amount of climate-change-related action is happening at the subnational level (Rabe 2011; Schaffer 2011; Matisoff and Edwards 2014; Bromley-Trujillo et al. 2016), our focus is on (comparative) national climate change policy output.
} 


\section{Measuring public demand (independent variable)}

To operationalise our theoretical construct, public demand, we need to translate its three facets, namely public interest, public opinion, and public debate, into measurable indicators. The data for our public demand variable is constructed based on a media content analysis of two newspapers in each of the six OECD countries - US, Canada, Germany, Switzerland, Italy, and Spain - and the observation period from 1995 to $2010^{9}$ (Oehl 2015; Oehl et al. 2017). The main advantage of this approach is that data can be collected ex post for any topic in any country for which online newspaper archives exist. Because we intended to test whether policymakers respond to the preferences of the public, we needed to take into account information sources policymakers are likely to use in order to gauge public sentiment. Many studies show that the main information source for policymakers indeed is the news media (Herbst 1993, 1998; Powlick 1995), and that policymakers tend to consider published opinion to be equivalent to public opinion. At the conceptual level, we relate to Neidhardt, 1994, who views "public opinion as an output of public communication" (Eilders 1997, p. 1). We derived two indicators, published opinion and media salience, to proxy for public opinion and public interest as the most important elements of public demand for policy responsiveness (c.f. Lax and Philips 2009).

\section{Published opinion}

To proxy for the public opinion dimension of public demand (c.f. 3.2.), we used the published opinion in news media sources. In our media content analysis, we thus coded claims for more climate protection, for the preservation of the status quo, and claims for less climate protection ${ }^{10}$. Based on these claims, we then estimated the published opinion indicator. Claims (for or against climate change policies) are expressions of opinions and point towards the future; the claim-maker seeks to influence something beyond the sphere of their own immediate influence. ${ }^{11}$ Therefore, statements by government members were excluded. The requirement of a future orientation was also necessary to avoid endogeneity problems in the analysis. This means that statements appearing in the news media after the adoption of a policy (e.g. referring to the specific policy) were not coded as claims (since they appeared after the fact).

The question remains whether our focus on published opinion can produce a valid and reliable proxy for public demand for climate change policy. In a previous article (Oehl et al. 2017), we compared our public demand measures with the best available survey and Internet search data to determine whether there are some cross-correlations between those and our measures over time. Only in the US,

\footnotetext{
${ }^{9}$ For more details on the newspapers, download procedures, search strings, as well as the coding process by which claims (statements) were coded, the reader is referred to Section 1 of the appendix and the original publication referenced here.

${ }^{10} \mathrm{~A}$ claim can be a statement, a demand, an opinion given by an individual or an organisation or summaries of position articless, press statements, comments, and so on.

${ }^{11}$ Examples of claims include: "In May, the National Academies of Science reported to Congress that 'the U.S. should act now to reduce greenhouse gas emissions" (pro claim) (New York Times 28 October 2010); "A coalition of state and local politicians, American Indian tribes, preservationists and Cape Cod business operators oppose the project, saying the 130 wind turbines rising 440 feet above the surface of Nantucket Sound would spoil the ocean view and disrupt submerged Indian burial grounds" (con claim) (New York Times, 14 January 2010).
} 
however, we were able to obtain at least some time series data on climate change indicators. ${ }^{12}$ Moreover, the indicators we could compare our measures to foremostly proxied for the attention to or concern about global warming and climate change and thus, could not exactly approximate the demand for political responses on climate change (which our opinion measure is focused on). Overall, our study found that indeed the one period lag of the Gallup Most important problem question on the environment in the previous period is a decent predictor of our published opinion measure. While the cross-correlations with respect to issue salience are much higher, this result still gives us confidence in our choice of a more fine-grained indicator to proxy public demand for climate change policy.

To further deal with endogeneity, we use both the one year lag of published opinion (for the same reason) and the difference in published opinion from the previous to the current period $(\Delta)$. Therefore we can, with some caution, interpret our results as evidence of potential causal effects. In terms of measurement, published opinion captures the ratio of claims for (pro) and against (con) climate change action, defined as "pro" minus "con" claims divided by the total number of claims made within a certain time period (c.f. Oehl et al. 2017). Hence, a positive value of published opinion means a larger share of positive statements in relation to climate change policy, and vice versa for negative ones.

\section{Media salience}

Media salience captures the public interest (issue salience, c.f. 3.1.) aspect of public demand. It is an indicator of the relative issue salience of climate change compared to other topics covered in the news. As noted in the theory section above, issue salience is linked to the attentiveness of policymakers and should thus impact policy responsiveness. Our media salience variable measures the share of media articles on climate change as a percentage of the absolute number of articles in the given newspaper (Oehl et al. 2017). This can be considered the issue attention of the media towards climate change (Bromley-Trujillo and Poe 2020).

\section{Political debate}

As stipulated in the theoretical section above, we propose that higher (lower) issue salience may enhance (dampen) the effect of published opinion on public policy output. Accordingly, the indicator related to political debate reflects the conditional effects of opinion and salience. Since this is only a multiplicative interaction term consisting of published opinion and media salience that is used to test for the scope for action, it is not separately shown, but its influence on legislative activity in the area of climate change is assessed in the quantitative analysis.

\section{Descriptive evidence}

Figures $2 \mathrm{a}$ and $2 \mathrm{~b}$ show the demand and output data for the six countries in the sample. While salience levels differ to a wide extent by country, their development

\footnotetext{
${ }^{12} \mathrm{To}$ account for the robustness of our findings, our article also features some comparison of sparse data from two more countries of our sample - Germany and Spain.
} 


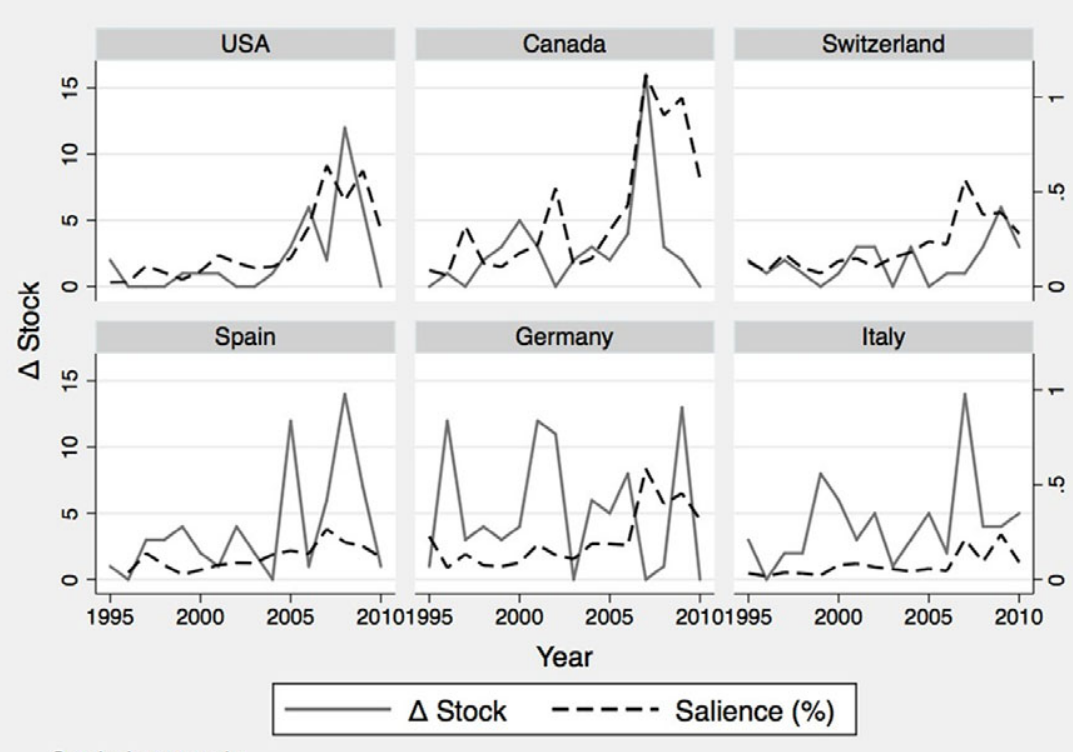

Graphs by cowcode

Figure 2a. Descriptive evidence: demand and output data (media salience).

Note: The $y$-axis on the left indicates the yearly number of climate change policies adopted and the right $y$-axis provides the scale for media salience.

over time is much smoother in most countries compared to the opinion variable. In 2007, US, German, and Swiss newspapers' relative share of reporting on climate change was three times greater than in their Spanish and Italian counterparts. In Canada, media salience was as much as six times as great. The peak in the number of adopted policies in Switzerland followed after the salience peak, and the largest increase in media salience. In general, Figures $2 \mathrm{a}$ and $2 \mathrm{~b}$ show us that media salience and policy output follow a similar trend, particularly in the US, Canada (with the exception of the year 2002), Switzerland, and Italy.

For the US and Canada, we observe that peaks in policy adoptions in 2007/08 follow after several years of very stable published opinion values. ${ }^{13}$ The positive values for published opinion throughout our time series indicate that claims in favour of climate protection have always prevailed in the countries and newspapers we studied. The values for published opinion in Italy drop suddenly in 2008 after a long period of stable values, following a large number of policy adoptions in 2007. This observation hints at a thermostatic adjustment. Spain and Germany have similar values for published opinion (and media salience), but Germany became active in policymaking much earlier and to a larger extent than Spain.

Analogous to our treatment of our two dependent variables (general responsiveness and target-specific responsiveness), the first analysis uses the overall values for

\footnotetext{
${ }^{13}$ For a figure displaying policy adoptions by country over time in one graph together with main climatechange-related events, the reader is referred to Figure A.2 in the appendix.
} 


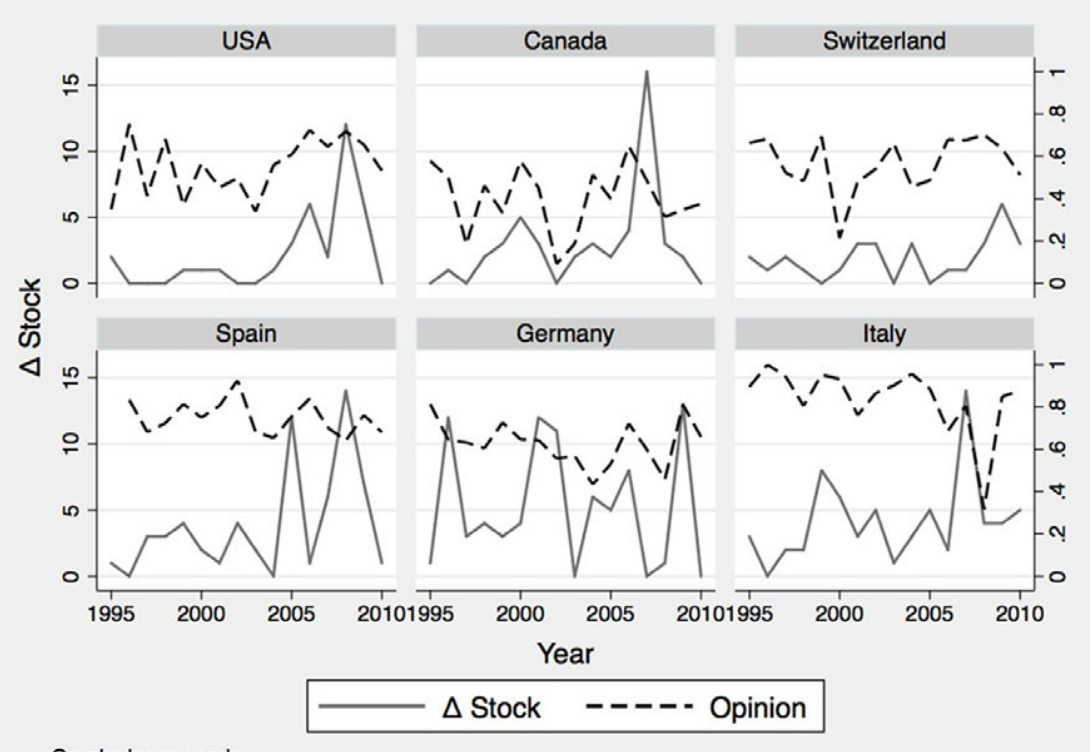

Graphs by cowcode

Figure 2b. Descriptive evidence: demand and output data (published opinion).

Note: The $y$-axis on the left indicates the yearly number of climate change policies adopted and the right $y$-axis provides the scale for published opinion.

published opinion and media salience, which are based on all articles related to climate change. The second analysis then relies on the target-specific versions, referred to as target opinion and target salience. To generate these measures, we again look at the relevant newspapers. For each policy target (specified in Figure A.1) we developed a search string with keywords related to the target and then used only articles that mentioned these keywords and the respective target at least twice (see Table A.2 in the appendix for the search strings and translations employed).

\section{Data and methods}

Table 2 provides an overview of all variables, how they are operationalised, and their data source (the corresponding summary statistics are shown in the appendix, Table A.3).

We are interested in explaining variation over time regarding the total number of policies adopted per year within and between countries ( $\Delta$ Stock) as well as with respect to different policy targets $(\Delta \text { (target)Stock })^{14}$. To this end, we analysed our time series and cross-sectional data with a random-effects panel model using

\footnotetext{
${ }^{14}$ Boehmke (2009) provides an overview of how the adoption of components of policies can be modelled. We follow Boehmke's advice in pooling the different policy components (policy targets) of climate change policy for our analysis.
} 
Table 2. Variables and data sources

\begin{tabular}{|c|c|c|c|}
\hline & Variable & Description & Source \\
\hline & $\Delta$ Stock & Number of new policies per year & Own data collection and coding \\
\hline & $\Delta$ (target)Stock & Number of new policies per year (for each of the policy targets) & Own data collection and coding \\
\hline & Stock $(\mathrm{t}-1)$ & $\begin{array}{l}\text { A one year lag of the stock (total number) of climate change policies } \\
\text { already in place }\end{array}$ & Own data collection and coding \\
\hline \multirow[t]{3}{*}{$\begin{array}{l}\text { IV: Measuring public } \\
\text { demand }\end{array}$} & Published opinion (3.1.2.) & Pro minus con claims divided by the total number of claims & $\begin{array}{l}\text { Own data collection and coding } \\
\text { (Author 2017) }\end{array}$ \\
\hline & Salience (3.1.1.) & $\begin{array}{l}\text { Share of articles (\%) that cover climate change in relation to total } \\
\text { number of articles in the newspaper(s) }\end{array}$ & $\begin{array}{l}\text { Own data collection and coding } \\
\text { (Author 2017) }\end{array}$ \\
\hline & Scope for action (3.1.3.) & Multiplicative interaction term of salience and published opinion & $\begin{array}{l}\text { Own data collection and coding } \\
\text { (Author 2017) }\end{array}$ \\
\hline \multirow[t]{5}{*}{$\begin{array}{l}\text { Control variables } \\
\text { (3.2.) }\end{array}$} & Share of left parties & $\begin{array}{l}\text { Cabinet composition: social democratic and other left-wing parties } \\
\text { as a percentage of total cabinet posts, weighted by the number of days } \\
\text { the government was in office in a given year. Name in source: gov_left1 }\end{array}$ & Armingeon et al. (2014) \\
\hline & Debt & Gross government debt (financial liabilities) as a percentage of GDP. & World development indicators \\
\hline & Growth & GDP growth (annual \%). Name in source: gdp_gr_pa & World development indicators \\
\hline & $\mathrm{CO}_{2}$ emissions & $\mathrm{CO}_{2}$ emissions (metric tons per capita). Name in source: co2_em_pc & World development indicators \\
\hline & Proportional representation & Dummy variable for proportional representation & Armingeon et al. (2014) \\
\hline
\end{tabular}


clustered standard errors at the country level ${ }^{15}$. Random effects were chosen because this enabled us to test both for the effect of demand within a country and between all countries. A Hausman test performed on the basic model (but without clustered standard errors) justified the use of random effects estimators.

To explain differences in climate change policy output $\left(y_{t}-y_{t-1}\right)$, we use both differences $\left(\mathrm{x}_{\mathrm{t}}-\mathrm{x}_{\mathrm{t}-1}\right)$ and (lagged) levels $\left(\mathrm{x}_{\mathrm{t}-1}\right)$ of the independent variables published opinion and salience. This allows us to examine how policymakers react when facing high and low levels of demand, and changes thereof. Both are potentially influential, as one could argue that policymakers react to sudden increases in public opinion from the past period or to higher levels because constant demand leads to action. Thus, if it is levels or differences that matter is ultimately an empirical question.

We also include a variable measuring the one year lag of the (target) stock (total number) of climate change policies already in place to model various patterns of policy adoption over time for both dependent variables (Boehmke 2009:8). Over time, we would expect to either observe potential path dependency (countries having already adopted several climate policies may develop an appetite for enacting more) or saturation (countries having already adopted several climate policies may not be willing to adopt even more).

\section{Results}

In this section, we first report results for the relationship between aggregate measures of public demand and climate policy output, wherein we analyse the general, unspecific demand for climate protection, including demand for various policies, and the general policy output (general responsiveness). We then look at specific targets of climate policymaking (e.g. buildings, and appliances) and explore whether target-specific demand has an effect on target-specific policy output (target-specific responsiveness).

\section{The effect of aggregate demand on aggregate climate policy output (general responsiveness)}

The aim of the analysis here is to test our main hypothesis that public demand, alongside partisanship and institutional factors, influences climate policymaking. The outcome variable in this analysis indicates how many new policies have been enacted altogether (within the four sectors shown in Figure A.1) in a given year. Table 3 shows the results of the basic models with our demand measures regressed on the policy output measure (Models 1-4).

As shown in Table 3, we observe that both a higher level of support for climate protection and an increase thereof from one period to the next leads to more climate policy adoption. When there are as many claims for and against climate protection in the previous period (opinion, $\mathrm{t}-1=0$ ) and only claims for climate protection in the current period ( $\Delta$ opinion $=1$ ), we expect to observe 4.5 new policy adoptions. Thus, with all models, positive (negative) public opinion (claims regarding climate

\footnotetext{
${ }^{15}$ While time series analysis is most dominantly used in responsiveness studies, as most articles examine only one country (Wlezien 1995; Hays et al. 1996; Agnone 2007), the use of panel analysis is typically applied when the analysis includes several or many countries (Dolšak and Houston 2014) over time.
} 
Table 3. Basic models (general responsiveness)

\begin{tabular}{lllll}
\hline$\Delta$ Stock (general responsiveness) & \multicolumn{1}{c}{$(1)$} & \multicolumn{1}{c}{$(2)$} & \multicolumn{1}{c}{$(3)$} & $(4)$ \\
\hline Policy stock, t-1 & $0.04^{\star \star}$ & $0.04^{\star \star}$ & 0.03 & 0.03 \\
& $(2.26)$ & $(2.15)$ & $(1.57)$ & $(1.20)$ \\
Opinion, t-1 & $4.33^{\star \star}(2.48)$ & & $5.77^{\star \star \star}(2.96)$ & $4.27^{\star \star}(2.04)$ \\
$\Delta$ Opinion & $4.50^{\star \star \star}(3.10)$ & & $5.91^{\star \star \star}(3.54)$ & $6.18^{\star \star \star}(3.24)$ \\
Salience (\%), t-1 & & 1.10 & $3.71^{\star \star}$ & -1.59 \\
& & $(0.73)$ & $(2.33)$ & $(-0.45)$ \\
$\Delta$ Salience (\%) & & $5.02^{\star}(1.65)$ & $6.01^{\star}(1.85)$ & $5.17^{\star \star}(2.51)$ \\
Scope, t-1 & & & 10.32 \\
& & & & $(1.34)$ \\
$\Delta$. Scope & & & -5.24 \\
& & & & $(-0.25)$ \\
Constant & & & & $-0.58(-0.34)$ \\
Observations & & & & 89 \\
r2_w & $89.04(-0.03)$ & $2.31^{\star \star}(2.49)$ & $-1.45(-0.94)$ & 0.13 \\
r2_b & 0.03 & 89 & 89 & 0.65 \\
r2_o & 0.66 & 0.04 & 0.11 & 0.17 \\
rmse & 0.10 & 0.78 & 0.72 & 3.57 \\
\hline
\end{tabular}

$t$ statistics in parentheses.

${ }^{\star} p<0.10,{ }^{\star *} p<0.05,{ }^{\star \star *} p<0.01$.

change) is related to more (less) policy output. The same applies to the salience of the issue of climate change. While the interaction effect between salience and opinion, which measures scope for action (or public debate), does not seem to be significantly related to policy output, graphical inspection of the predictive margins (see appendix Figure A.3a/b) shows that salience does indeed enhance the effect of opinion on policy output. This is the first confirmation of our expectations regarding the conditionality of opinion and salience, which we will return to in our detailed analysis of the interaction effects below. Overall, it seems to be opinion rather than the mere salience of an issue (measured via the climate-change-relevant articles) that drives policy output. This indicates that our efforts to come up with a more accurate measure of published opinion are indeed adding something to our knowledge about the process of how public demand may turn into policy. Given that most studies only analyse the salience of climate change in the media (Schmidt et al. 2013; Schäfer et al. 2014; Anderson et al. 2017), our measure makes a novel contribution to the field.

In the following models in Table 4, we estimate the effects of different combinations of the explanatory factors discussed in the theory section. ${ }^{16}$ The effects of opinion, both in terms of level and change, and the level of salience are robust to the inclusion of control variables. Of these control variables, only partisanship matters: a higher share of cabinet posts held by left party members significantly increases the number of climate protection policies that are adopted. The strong results for partisanship are all the more powerful when we consider that the situation in two countries in the sample clearly deviates from the hypothesised pattern. In Switzerland, the composition of the government is predetermined and fixed (a

\footnotetext{
${ }^{16}$ The covariates are added to the basic models in groups. This approach was chosen because the number of observations is rather small.
} 
Table 4. Basic models for general responsiveness with stepwise inclusion of control variables

\begin{tabular}{|c|c|c|c|c|c|}
\hline$\Delta$ Stock (general responsiveness) & (1) & $(2)$ & (3) & (4) & (5) \\
\hline Stock, t-1 & $\begin{array}{l}-0.01 \\
(-0.31)\end{array}$ & $\begin{array}{l}0.02 \\
(0.43)\end{array}$ & $\begin{array}{l}-0.01 \\
(-0.21)\end{array}$ & $\begin{array}{l}-0.02 \\
(-0.41)\end{array}$ & $\begin{array}{l}-0.02 \\
(-0.30)\end{array}$ \\
\hline Opinion, t-1 & $\begin{array}{l}3.70^{\star} \\
(1.94)\end{array}$ & $\begin{array}{l}3.13 \\
(1.07)\end{array}$ & $\begin{array}{l}4.37^{\star} \\
(1.85)\end{array}$ & $\begin{array}{l}4.29^{\star} \\
(1.79)\end{array}$ & $\begin{array}{l}4.47^{\star \star \star} \\
(2.67)\end{array}$ \\
\hline$\Delta$ Opinion & $\begin{array}{l}6.13^{\star \star \star} \\
(3.72)\end{array}$ & $\begin{array}{l}5.77^{\star \star \star} \\
(3.76)\end{array}$ & $\begin{array}{l}6.38^{\star \star \star} \\
(4.78)\end{array}$ & $\begin{array}{l}5.85^{\star \star \star} \\
(3.77)\end{array}$ & $\begin{array}{l}4.71^{\star \star} \\
(2.18)\end{array}$ \\
\hline Salience, $\mathrm{t}-1$ & $\begin{array}{l}0.28 \\
(0.08)\end{array}$ & $\begin{array}{l}-1.06 \\
(-0.28)\end{array}$ & $\begin{array}{l}0.08 \\
(0.02)\end{array}$ & $\begin{array}{l}-1.55 \\
(-0.54)\end{array}$ & $\begin{array}{l}1.56 \\
(0.46)\end{array}$ \\
\hline$\Delta$ Salience & $\begin{array}{l}6.16^{\star \star \star} \\
(3.66)\end{array}$ & $\begin{array}{l}5.69^{\star \star} \\
(2.28)\end{array}$ & $\begin{array}{l}5.90^{\star \star \star} \\
(2.83)\end{array}$ & $\begin{array}{l}4.65^{\star \star} \\
(2.03)\end{array}$ & $\begin{array}{l}4.39 \\
(1.30)\end{array}$ \\
\hline Scope, $t-1$ & $\begin{array}{l}11.56^{\star} \\
(1.78)\end{array}$ & $\begin{array}{l}10.78 \\
(1.30)\end{array}$ & $\begin{array}{l}11.36^{\star} \\
(1.79)\end{array}$ & $\begin{array}{l}12.33^{\star} \\
(1.85)\end{array}$ & $\begin{array}{l}12.98 \\
(1.60)\end{array}$ \\
\hline$\Delta$ Scope & $\begin{array}{l}-0.39 \\
(-0.02)\end{array}$ & $\begin{array}{l}-5.33 \\
(-0.26)\end{array}$ & $\begin{array}{l}-0.02 \\
(-0.00)\end{array}$ & $\begin{array}{l}-7.74 \\
(-0.49)\end{array}$ & $\begin{array}{l}-2.45 \\
(-0.11)\end{array}$ \\
\hline $\begin{array}{l}\text { Left parties (\%) as proportion of } \\
\text { total cabinet posts weighted } \\
\text { by days }\end{array}$ & $\begin{array}{r}0.04^{\star \star \star} \\
(4.30)\end{array}$ & & $\begin{array}{l}0.04^{\star \star \star} \\
(10.12)\end{array}$ & $\begin{array}{l}0.04^{\star \star \star} \\
(12.98)\end{array}$ & $\begin{array}{l}0.04^{\star \star \star} \\
(10.04)\end{array}$ \\
\hline Proportional representation & & $\begin{array}{l}0.89 \\
(0.49)\end{array}$ & $\begin{array}{l}-0.55 \\
(-0.34)\end{array}$ & $\begin{array}{l}-0.84 \\
(-0.50)\end{array}$ & $\begin{array}{l}2.98 \\
(0.59)\end{array}$ \\
\hline GDP growth (annual \%) & & & $\begin{array}{l}-0.37 \\
\quad(-1.46)\end{array}$ & & \\
\hline $\begin{array}{l}\mathrm{CO}_{2} \text { emissions (metric tons per } \\
\text { capita) }\end{array}$ & & & & & $0.36(0.80)$ \\
\hline Constant & -0.92 & -0.43 & -1.04 & 0.34 & -7.49 \\
\hline Observations & 89 & 89 & 89 & 89 & 77 \\
\hline r2_w & 0.23 & 0.14 & 0.22 & 0.26 & 0.24 \\
\hline r2_b & 0.48 & 0.50 & 0.56 & 0.52 & 0.57 \\
\hline r2_o & 0.26 & 0.18 & 0.26 & 0.29 & 0.28 \\
\hline rmse & 3.40 & 3.58 & 3.42 & 3.37 & 3.43 \\
\hline
\end{tabular}

quasi-permanent large coalition) and does not change after elections. Additionally, in Germany, climate policy has become a topic without clear issue ownership by any party. In fact, Chancellor Angela Merkel from the country's main conservative party has frequently been referred to as the "Klimakanzlerin" ("climate chancellor").

\section{Target-specific demand and policy output}

We now examine the impact of target-specific public demand (target-related opinion and salience) on policymaking with respect to those targets ( $\Delta$ target stock). To create target-specific public demand we used different search strings for each of the policy targets (renewable energy supply, fossil fuel supply, private transport, public transport, buildings, and appliances; for more information, the reader is referred to the appendix, Table A.2). We believe that this disaggregation should significantly add to our understanding of the workings of issue-specific policy responsiveness by making it possible to map demand onto policy output in a more fine-grained way. Using target-specific demand confronts our hypothesis of climate change policy responsiveness with a stronger test to see whether the responsiveness link we find overall is also present in terms of target-specific responsiveness. 

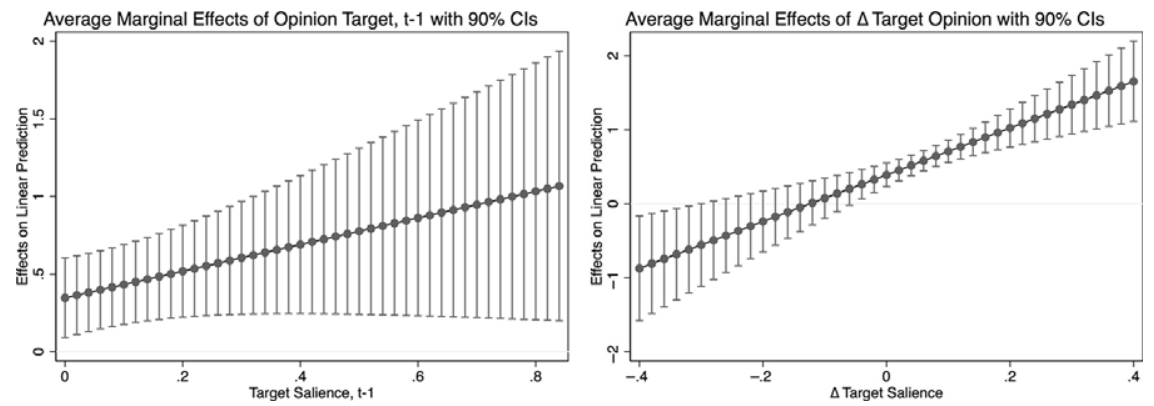

Figure 3 Interaction effects of salience and opinion (scope for action).

The first three models in Table 5 show the basic models, while the following Models 4-6 include the covariates. ${ }^{17}$ Indeed, we can see again, that of the targetspecific public demand measures, especially our measure on the target-specific opinion is significantly related to target-specific policy output. Both measures show the hypothesised sign and are significantly and robustly related to target-specific policy output throughout all of the models. Thus, more claims for target-specific climate change policy increase the responsiveness of policymakers. Moreover, as argued above, issue salience and opinion may have mutually enhancing effects on legislative activity. Thus, our demand measure of scope for action sheds light on whether the main effect of published opinion on policy output changes for different levels of salience; i.e. on whether the more salient an issue is, the greater the effect of opinion on policy responsiveness is likely to be. We indeed find some significant effects when interacting both level variables and the two differences with each other. For two coefficients of the interaction, one on levels, the other on differences, we plotted the average marginal effect given the changing values of the other variable (see Figure 3, and Table A.4 in the appendix). In the left part of Figure 3, we can see that a higher level of salience in the previous period increases the impact targetspecific opinion has on policy output, but confidence intervals are large. However, it could also be that policymakers react to changes in the salience rather than the levels, for example, a marked rise in articles about renewable energy from one year to the next. Above we have argued that positive (negative) changes in salience will amplify (dampen) the effect of our opinion measure on policy responsiveness. Indeed, from the right part of Figure 3, we can see that an increase in salience combined with an increase in the share of positive claims boosts the impact both factors have on policy output. Policymakers indeed seem to react to positive target-specific opinions on given targets much more if these targets have also become more salient and thus potentially promise a higher electoral reward for policy action.

Lastly, in contrast to our findings regarding the general responsiveness, we here find the first indication for path dependency with respect to policy targets, as the coefficient on the lagged policy stock of the respective targets (target stock $\mathrm{t}-1$ )

\footnotetext{
${ }^{17}$ Since we pool the observations for the policy targets for which we collected data, the number of observations increases.
} 
Table 5. Basic models for target-specific responsiveness with stepwise inclusion of control variables

DV: $\Delta$ Target Stock (target-specific responsiveness)

(1)

(2)

(3)

Target stock, $\mathrm{t}-1$

Target opinion, $\mathrm{t}-1$

$\Delta$ Target opinion

Target salience, $\mathrm{t}-1$

$\Delta$ Target salience

Target scope, $\mathrm{t}-1$

$\Delta$ Target scope

Left-wing parties (\%) as

proportion of total cabinet posts

$0.05^{\star \star \star}$
$(6.58)$
$0.43^{\star \star \star}$
$(2.62)$
$0.39^{\star \star \star}$
$(4.02)$

$0.05^{\star \star \star}$

$0.05^{\star \star \star}$

(6.15)

(6.52)

$0.41^{\star \star \star}$

(3.14)

$0.39^{\star \star \star}$

$\begin{array}{ll} & (3.91) \\ -0.21^{\star \star \star} & -0.41\end{array}$

$(-2.62)$

$(-0.91)$

$-0.11$

$-0.20$

$(-0.31)$

0.43

(0.49)

$2.99^{\star \star \star}(2.82)$

$\quad(4)$
$0.04^{\star \star \star}$
$(6.76)$
$0.34^{\star \star}$
$(2.47)$
$0.35^{\star \star \star}$
$(3.48)$
-0.29
$(-0.62)$
-0.07
$(-0.12)$
0.40
$(0.46)$
$2.73^{\star \star \star}(2.76)$

(5)

$0.05^{\star \star \star}$

(5.82)

$0.40^{\star \star \star}$

(3.02)

$0.38^{\star \star \star}$

(4.54)

$-0.38$

$(-0.68)$

$-0.19$

$(-0.32)$

0.40

(0.41)

$2.98^{\star \star \star}(2.86)$

$0.00^{\star \star \star}$

(3.73)

weighted by days

Proportional

representation

GDP growth (annual \%)

$\mathrm{CO}_{2}$ emissions (metric tons

per capita)

Constant

Observations

r2_w

r2_b

r2_o

rmse

$\begin{array}{lll} & & \\ & & \\ & & \\ & & \\ & & \\ & & \\ 0.16 & 0.42^{\star \star \star} & 0.20^{\star \star} \\ (1.27) & (5.75) & (2.36) \\ 534 & 534 & 534 \\ 0.00 & 0.00 & 0.00 \\ 0.74 & 0.77 & 0.71 \\ 0.07 & 0.06 & 0.07 \\ 0.99 & 1.00 & 0.99\end{array}$

\subsection{2}

$(0.20)$

$(6)$

$0.03^{\star \star \star}$

(4.63)

$0.36^{\star \star}$

(2.26)

$0.35^{\star \star \star}$

(3.73)

$-0.47$

$(-0.98)$

0.17

$(0.37)$

0.58

(0.70)

$3.10^{\star \star \star}(2.75)$

$0.00^{\star \star \star}$

(2.92)

*

$0.04^{\star *}$

$(1.98)$

$0.38^{\star \star}$

(2.15)

$0.33^{\star \star}$

(2.47)

$-0.57$

$(-1.26)$

0.27

$(0.67)$

0.68

(0.77)

$3.21^{\star \star \star}(3.00)$

$0.00^{\star \star}$

(2.12)

$-0.19$

$(-1.61)$

$-0.04$

$-0.06$

$(-1.48)$

$(-0.06)$

0.02

(0.28)

$-0.03$

$(-0.03)$

(3.07)

(2.66)

(1.85)

534

0.01

0.58

0.09

0.99

534

0.00

0.70

0.07

0.99

462

0.02

0.03

0.61

0.60

0.10

0.10

$t$ statistics in parentheses.

${ }^{\star} \mathrm{p}<0.10,{ }^{\star \star}{ }^{\circ} \mathrm{p}<0.05,{ }^{\star \star \star}{ }^{\circ} \mathrm{p}<0.01$. 

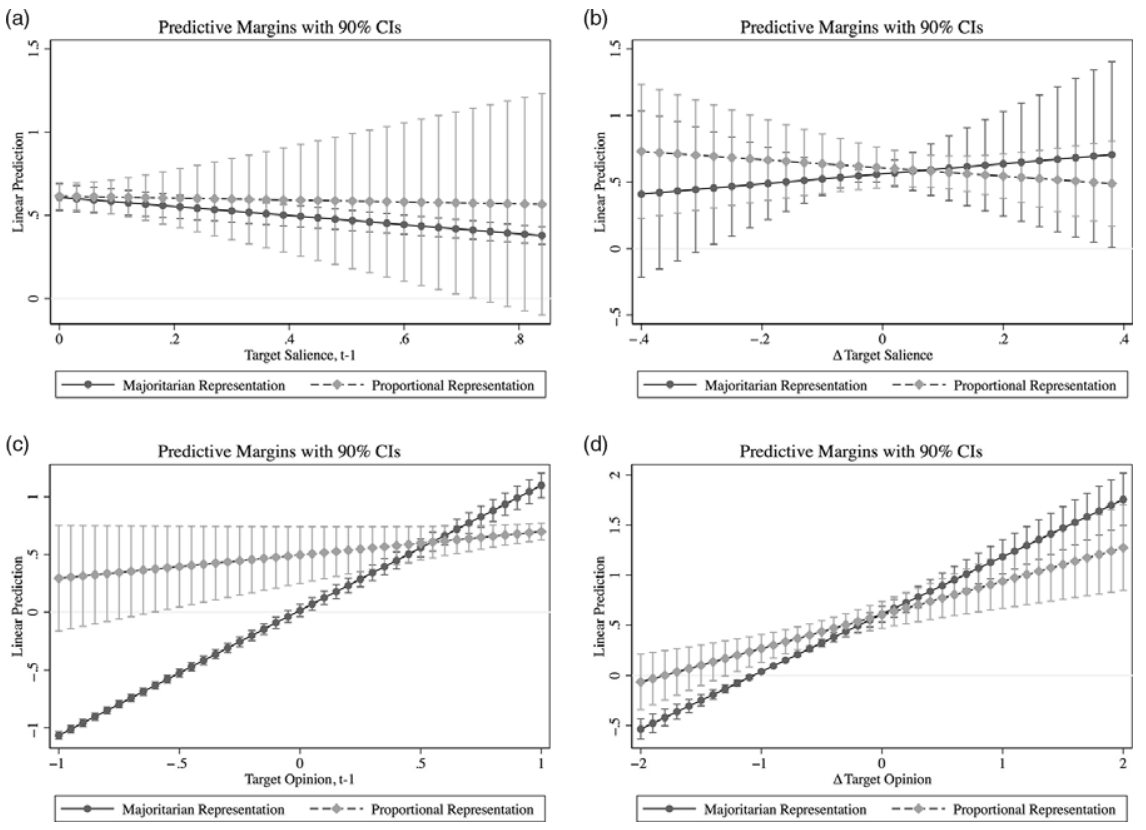

Figure 4 Interaction effect of the electoral system with our four public demand measures.

shows a robustly significant effect in all models of Table 5 . That is, more targetspecific policies adopted earlier are associated with more policies in the following period.

Models 4-7 then include political and institutional variables, such as the partisanship of the government and the electoral system. Counter to what we had hypothesised for the electoral systems, we find that systems with proportional representation are less likely to adopt target-specific policies. However, institutional variables as the electoral system may also moderate the influence of public demand on policy output. To this end, we estimated models with interaction terms for the demand indicators and the electoral system (Table A.5 in the appendix).

Figure $4(\mathrm{a}-\mathrm{d})$ shows, for the purpose of illustration, the effects on the linear prediction for different electoral systems for both our measures of lagged opinion and salience (subfigures a and c) and for the changes in opinion and salience from the previous period (subfigures $b$ and $d$ ).

The most striking result from interacting our demand measures with the electoral system lies in the differentiated reaction to published opinion on a certain target (subfigures $\mathrm{c}$ and $\mathrm{d}$ ). While for countries with proportional representation, the level of target opinion seems to have very little (cf. subfigure c) effect on policymaking, in majoritarian electoral systems policy output is clearly affected by the positive or negative levels of published opinion. Hence, the more positive (negative) the opinion with respect to climate change policy in the previous period (Target opinion $_{\mathrm{t}-1}$ ) is, the more positive (negative) is the effect on the target-specific policy output. An increase (decrease) in the calls for action ( $\Delta$ Target opinion) (subfigure d) 
has a positive (negative) effect on the target-specific policy output for both electoral systems, however, also there, the relation is steeper for majoritarian systems. Quite contrarily, from subfigures a and b, we can conclude that the effect of the electoral system on the number of adopted policies does not vary significantly with respect to the level and changes of the salience of a target.

While these are interesting findings suggesting that policymakers in majoritarian systems are more sensitive to levels and change in the sentiment of published opinion on climate change action, in light of our small sample on the country level, these results might be driven by country-specific factors that coincide with the electoral systems. Hence, we should interpret them with caution. Future cross-country comparative studies may consider the conditioning effect the electoral system has on the link between public demand and output and see whether our results hold in a broader context.

\section{Discussion and conclusion}

Our main result is that public demand, measured in terms of overall media salience and calls for or against climate change mitigation (published opinion) matters in relation to the total number of climate change mitigation policies that are adopted. That is, we are able to show that policy output in the area of climate change is affected quite consistently by changes in published opinion - i.e. the more direct claims put forward within news media - whereas, the effect of mere issue salience is not so clear cut. This demonstrates the added value of using a more comprehensive measure of public demand for climate change policies.

Moreover, disaggregating both the public demand and our policy output measures at the climate policy target level (e.g. whether a policy targets the buildings or the transport sector) supports our main findings. Overall, more positive opinions (those that demand more climate action) are robustly and significantly related to policy output. The effect of issue salience is strongest in combination with an opinion as this creates a scope for action. Another finding of our target-related analysis is that the lagged policy stock has a consistently positive effect in the large majority of our statistical models. We cautiously interpret this as positive news from a climate change mitigation perspective as it suggests path dependency rather than a saturation effect (c.f. Aklin and Urpelainen 2013). That is, it suggests that when countries adopt more climate mitigation policies at one point in time, this makes them more likely to adopt climate change mitigation policies thereafter, rather than less.

Additionally, we examined the (moderating) influences of several political/institutional factors. For partisanship of government, we found that leftist governments not only adopt more climate policies, but also appear to be more responsive to public demand. The type of electoral system indirectly affects climate policymaking via demand: especially policymakers in majoritarian systems seem to react much more strongly to the opinion measure of public demand, compared to their counterparts in political systems with proportional representation.

By and large, we thus observe a considerable degree of responsiveness of policymakers to public demand in the climate policy area right from the beginning of serious national climate change efforts in the mid-1990s. This finding is new 
and important for at least three reasons. First, whereas the large majority of related studies deal with high salience issues and thus run the risk of confirmatory bias, our study deals with a moderate saliency issue. The fact that we still observe a considerable degree of responsiveness can be regarded as good news from a normative perspective as it emphasises that the main advantage of democracy is that policymakers are more accountable, and thus also more responsive, to public demand.

Second, whereas the large majority of related studies cover one single country over time, or compare subnational units within one country, our study is the first to compare the climate change policy output of several countries over time to find that responsiveness to public demand is present in different country contexts. Moreover, we find interesting differences on how public demand for climate change is linked to policy output depending on institutional factors such as the electoral system. Future research may study more thoroughly the (institutional and political) context conditions of climate policy responsiveness.

Third, our study is the first within the broader realm of comparative environmental studies to disaggregate both the public demand and our policy output measures at the climate policy target level (e.g. whether a policy targets the buildings or the transport sector). Employing such a fine-grained test of policy responsiveness, we still find a considerable degree of responsiveness, especially concerning changes in published opinion. Future studies should inquire in more detail how responsiveness differs between countries and policy targets, and why this may be the case.

While our contribution made headway to address the problems associated with measuring demand, there are - of course - many remaining questions. The broader issues connected to our measure are whether, first, our method focusing on published opinion can produce a valid and reliable proxy for public opinion, and second whether published opinion as such can be measured in a valid and reliable manner and acts as a driver of climate policy choices. These two issues are connected in our case in the sense that we are trying to show not only that published opinion drives climate policy choices (this may also apply in an autocracy), but also that this reflects a policy responsiveness mechanism in liberal democracies - and this requires that published opinion reflects public opinion of the demos. However, at this stage, we do not have enough high-quality and commensurable survey data for several countries over time to run robust tests of the hypotheses we have outlined. Hence, our concepts and empirical measures for published opinion/demand are a good alternative, and perhaps the only one for the time being. Our comprehensive assessment in another article (Oehl et al. 2017) has shown that we have a good proxy, and we also think our data coding effort has been comprehensively conducted and has addressed potential endogeneity problems well. Overall, we thus are quite confident that our results speak not only to whether published opinion affects policy choices (which could be the case also in autocracies), but contributes to the policy responsiveness debate in democracies.

As a final remark, future research needs to look more carefully into whether climate change mitigation policies that are adopted are effective at reducing GHG emissions - this task is beyond the scope of this article (Eskander and Fankhauser 2020). Indeed, a high degree of responsiveness of policy output to variation in public demand does not necessarily bring about ambitious climate policies as there appears to be a gap between words and deeds in this area, particularly in 
democratic countries (as observed by Bättig and Bernauer 2009). High-quality democracy in terms of responsiveness is not necessarily inductive to deeper cuts in GHG emissions, but means that citizens tend to get from the government what they want (and thus deserve).

Acknowledgements. The authors would like to thank Alba Mohedano Roldán, Basil Schläpfer, Brittany Rodriguez, Nicole Ponta, Pascal Scheiwiller, Pia Struntz, Samantha Suarez, Sara Eliason, and Florian Lichtin for their excellent research assistance in data collection and coding. Funding by the Swiss National Science Foundation (SNSF) within the project "Explaining Spatial and Temporal Dynamics in Climate Change Policy Making” (100017_135261) is gratefully acknowledged. We also thank participants of the Brownbag Seminar Series at the University of Konstanz, the Midwest Political Science Association Annual Meeting 2018, and the staff seminar at the University of Geneva in May 2018 and two anonymous reviewers for their helpful comments. Replication materials are available at: https://doi.org/10.7910/DVN/ WPRN15.

Data availability statement. Replication materials are available in the Journal of Public Policy Dataverse at: https://doi.org/10.7910/DVN/WPRN15.

Supplementary material. To view supplementary material for this article, please visit https://doi.org/10. 1017/S0143814X21000088.

\section{References}

Agnone J (2007) Amplifying public opinion: The policy impact of the US environmental movement. Social Forces, 85(4): 1593-1620. doi: 10.1353/sof.2007.0059

Aklin M and Urpelainen J (2013) Political competition, path dependence, and the strategy of sustainable energy transitions. American Journal of Political Science, 57(3): 643-658.

Allison PD (2009) Fixed Effects Regression Models. Sage Publications. doi: 10.1111/ajps.12002

Anderson B, Böhmelt T and Ward H (2017) Public opinion and environmental policy output: a crossnational analysis of energy policies in Europe. Environmental Research Letters, 12(11): 114011.

Armingeon K, Knöpfel L, Weisstanner D and Engler S (2014) Comparative Political Data Set III 1960-2012.

Bakaki Z, Böhmelt T and Ward H (2020) The triangular relationship between public concern for environmental issues, policy output, and media attention. Environmental Politics, 29(7): 1157-1177.

Bättig MB and Bernauer T (2009) National institutions and global public goods: are democracies more cooperative in climate change policy? International Organization, 63(2): 281-308.

Beiser-McGrath LF and Bernauer T (2019). Could revenue recycling make effective carbon taxation politically feasible? Science Advances, 5(9): eaax3323. doi: 10.1126/sciadv.aax3323

Bélanger É and Meguid BM (2008) Issue salience, issue ownership, and issue-based vote choice. Electoral Studies, 27(3): 477-491. doi: 10.1016/j.electstud.2008.01.001

Bernauer T (2013) Climate change politics. Annual Review of Political Science, 16, 421-448.

Bernauer T and Böhmelt T (2013) Are Economically "Kinder, Gentler Societies" also Greener? Environmental Science \& Technology, 47(21): 11993-12001.

Boehmke FJ (2009) Approaches to Modeling the Adoption and Diffusion of Policies with Multiple Components. State Politics \& Policy Quarterly, 9(2): 229-252. doi: 10.1177/153244000900900205

Bromley-Trujillo R and Poe J (2020). The importance of salience: public opinion and state policy action on climate change. Journal of Public Policy, 40(2): 280-304.

Bromley-Trujillo R, Butler JS, Poe J and Davis W (2016) The spreading of innovation: State adoptions of energy and climate change policy. Review of Policy Research, 33(5): 544-565.

Brooks JE (1985) Democratic frustration in the Anglo-American polities: A quantification of inconsistency between mass public opinion and public policy. The Western Political Quarterly, 38(2): 250-261.

Brooks JE (1987) The opinion-policy nexus in France: Do institutions and ideology make a difference The Journal of Politics, 49(2): 465-480. 
Brulle RJ, Carmichael J and Jenkins JC (2012). Shifting public opinion on climate change: an empirical assessment of factors influencing concern over climate change in the US, 2002-2010. Climatic Change, 114(2): 169-188.

Burck J, Marten F and Bals C (2014) The Climate Change Performance Index Results 2015.

Burstein P (2003) The impact of public opinion on public policy: A review and an agenda. Political Research Quarterly, 56(1): 29-40.

Burstein P (2006) Why estimates of the impact of public opinion on public policy are too high: Empirical and theoretical implications. Social Forces, 84(4): 2273-2289.

Burstein P (2010) Public opinion, public policy, and democracy. In Handbook of Politics. New York: Springer, 63-79.

Burstein P (2014) American Public Opinion, Advocacy, and Policy in Congress: What the Public Wants and what it Gets. New York: Cambridge University Press.

Buttice M and Highton B (2013) How Does Multilevel Regression and Poststratification Perform with Conventional National Surveys? Political Analysis, 21(4): 449-467. doi: 10.1093/pan/mpt017

Caughey D and Warshaw C (2018) "Policy preferences and policy change: Dynamic responsiveness in the American states, 1936-2014." American Political Science Review, 112(2): 249-266.

Dahl RA (1956) A preface to democratic theory. Chicago: University of Chicago Press.

Dahl RA (1971) Polyarchy, participation and opposition. New Haven: Yale University Press, 257.

Dolšak N and Houston K (2014) Newspaper Coverage and Climate Change Legislative Activity across US States. Global Policy, 5(3): 286-297. doi: 10.1111/1758-5899.12097

Donner SD, and McDaniels J (2013) The influence of national temperature fluctuations on opinions about climate change in the U.S. since 1990. Climatic Change, 118(3-4): 537-550. doi: 10.1007/s10584-0120690-3

Douenne T and Fabre A (2020) French attitudes on climate change, carbon taxation and other climate policies. Ecological Economics, 169, 106496.

Downs A (1957) An economic theory of democracy. New York: Harper \& Row.

Eilders C (1997) The impact of editorial content on the political agenda in Germany. Theoretical assumptions and open questions regarding a neglected subject in mass communication research.

Eskander SMSU and Fankhauser S (2020) Reduction in greenhouse gas emissions from national climate legislation. Nature Climate Change, 10: 750-756. https://doi.org/10.1038/s41558-020-0831-z

Fankhauser S, Gennaioli C and Collins M (2014) Domestic dynamics and international influence: What explains the passage of climate change legislation? Centre for Climate Change Economics and Policy Working Paper, (156).

Fredriksson PG and Millimet DL (2004) Electoral rules and environmental policy. Economics Letters, 84(2): 237-244. doi: 10.1016/j.econlet.2004.02.008

Grimmer J and Stewart B (2013) Text as data: The promise and pitfalls of automatic content analysis methods for political texts. Political Analysis, 21, 267-297.

Hamilton LC, Hartter J and Bell E (2019) Generation gaps in US public opinion on renewable energy and climate change. PloS one, 14(7): e0217608.

Hardin G (1968) The tragedy of the commons. Science, 162(June): 1243-1248.

Harrison K and Sundstrom LM (2007) The comparative politics of climate change. Global Environmental Politics, 7(4): 1-18.

Hays SP, Esler M and Hays CE (1996) Environmental commitment among the states: Integrating alternative approaches to state environmental policy. Publius: The Journal of Federalism, 26(2): 41-58.

Herbst S (1993) Numbered voices. How opinion polling has shaped American politics. Chicago: University of Chicago Press.

Herbst S (1998) Reading public opinion: how political actors view the democratic process. Chicago: University of Chicago Press.

Hobolt SB and Klemmemsen R (2005) Responsive government? Public opinion and government policy preferences in Britain and Denmark. Political Studies, 53(2): 379-402. doi: 10.1111/j.1467-9248.2005. 00534.x

Holzinger K, Knill C and Sommerer T (2008) Environmental policy convergence: the impact of international harmonization, transnational communication, and regulatory competition. International Organization, 62(4): 553-587. 
Hughes L and Urpelainen J (2015) Interests, institutions, and climate policy: Explaining the choice of policy instruments for the energy sector. Environmental Science \& Policy, 54, 52-63.

Johnson M, Brace P and Arceneaux K (2005) Public opinion and dynamic representation in the american states: The case of environmental attitudes*. Social Science Quarterly, 86(1): 87-108.

Jones BD and Baumgartner FR (2005). The Politics of Attention: How Government Prioritizes Problems. Chicago: University of Chicago Press.

Kachi A, Bernauer T and Gampfer R (2015) Climate policy in hard times: Are the pessimists right? Ecological Economics, 114, 227-241.

Konisky D, McAdam D and Urpelainen J (2017) From Demand to Policies and Outcomes: A Research Agenda for Scholars of Climate Policy. NY: SSRC Report.

Lachapelle E, Borick CP and Rabe B (2012) Public Attitudes toward Climate Science and Climate Policy in Federal Systems: Canada and the United States Compared1. Review of Policy Research, 29(3): 334-357.

Lax JR and Phillips JH (2009) Gay rights in the states: Public opinion and policy responsiveness. American Political Science Review, 103(3): 367-386.

Lax JR and Phillips JH (2012) The democratic deficit in the states. American Journal of Political Science, 56(1): 148-166.

Lee TM, Markowitz EM, Howe PD, Ko C-Y and Leiserowitz AA (2015) Predictors of public climate change awareness and risk perception around the world. Nature Climate Change, 5(11): 1014-1020.

Leiserowitz A (2006) Climate change risk perception and policy preferences: The role of affect, imagery, and values. Climatic Change, 77(1-2): 45-72.

Loftis MW and Mortensen PB (2018) Collaborating with the Machines: a hybrid method for classifying policy documents. Policy Studies Journal. doi: 10.1111/psj.12245

Lorenzoni I and Pidgeon NF (2006) Public views on climate change: European and USA perspectives. Climatic Change, 77(1-2), 73-95.

Schaffer LM and Lüth M (2021) Domestic political consequences of climate change: The evolving party competition over climate and energy policy. Working paper.

Masson-Delmotte V, Zhai P, Pörtner HO, Roberts D, Skea J, Shukla PR and Waterfield T (2018) Global warming of 1.5 C. An IPCC Special Report on the impacts of global warming of, 1, 1-9.

Matisoff DC (2008) The Adoption of State Climate Change Policies and Renewable Portfolio Standards: Regional Diffusion or Internal Determinants? Review of Policy Research, 25(6): 527-546. doi: 10.1111/j. 1541-1338.2008.00360.x

Matisoff DC and Edwards J (2014) Kindred spirits or intergovernmental competition? The innovation and diffusion of energy policies in the American states (1990-2008). Environmental Politics, 23(5): 795-817.

McCright AM andDunlap RE (2011). The Politicization of Climate Change and Polarization in the American Public'S Views of Global Warming, 2001-2010. Sociological Quarterly, 52(2): 155-194. doi: 10.1111/j.1533-8525.2011.01198.x

Mildenberger M, Howe P, Lachapelle E, Stokes L, Marlon J and Gravelle T (2016) The distribution of climate change public opinion in Canada. PloS one, 11(8): e0159774.

Neidhardt F (1994) Öffentlichkeit, öffentliche Meinung, soziale Bewegungen. Wiesbaden: VS Verlag für Sozialwissenschaften.

Neumayer E (2003) Are left-wing party strength and corporatism good for the environment? Evidence from panel analysis of air pollution in OECD countries. Ecological Economics, 45(2): 203-220. doi: 10.1016/ S0921-8009(03)00012-0

Oehl B (2015) Public Demand and Climate Change Policy Making in OECD Countries: From Dynamics of the Demand to Policy Responsiveness (Doctoral dissertation, ETH Zurich https://doi.org/10.3929/ethz-a010432416).

Oehl B, Schaffer L and Bernauer T (2017) How to measure public demand for policies when there is no appropriate survey data? Journal of Public Policy, 37(2): 173-204.

Ostrom E, Gardner R and Walker J (1994) Rules, games, and common-pool resources. Ann Arbor: University of Michigan Press.

Perloff RM (1993) Third-person effect research 1983-1992: A review and synthesis.

Petry F and Mendelsohn M (2004) Public Opinion and Policy Making in Canada 1994-2001. Canadian Journal of Political Science, 37: 505-529. 
Pew Research Center (2019a) "Climate Change Still Seen as the Top Global Threat, but Cyberattacks a Rising Concern", http://www.pewglobal.org/2019/02/10/climate-change-still-seen-as-the-top-globalthreat-but-cyberattacks-a-rising-concern/ (accessed 10 March 2019).

Pew Research Center (2019b) "Public's Policy Priorities for 2019", ---http://www.pewresearch.org/facttank/2019/02/04/state-of-the-union-2019-how-americans-see-major-national-issues/pp_2019-01-24_ political-priorities_0-02/ (accessed 10 March 2019).

Powell GB (2000) Elections as instruments of democracy: Majoritarian and proportional visions. New Haven: Yale University Press.

Powlick P (1995) The sources of public opinion for American foreign policy officials. International Studies Quarterly, 39(4): 427-451.

Rabe B (2011) Contested federalism and American climate policy. Publius: The Journal of Federalism, 41(3): 494-521.

Ringquist EJ (1994) Policy influence and policy responsiveness in state pollution control. Policy Studies Journal, 22(1): 25-43.

Schäfer MS, Ivanova A and Schmidt A (2014) What drives media attention for climate change? Explaining issue attention in Australian, German and Indian print media from 1996 to 2010. International Communication Gazette, 76(2): 152-176.

Schaffer LM (2011) Voluntary climate change initiatives in the US: Analyzing participation in space and time (Doctoral dissertation, ETH Zurich). doi: 10.3929/ethz-a- 006465833x

Schaffer LM (2021) The Politics of Green Taxation. In Hakelberg L and Seelkopf L (eds.), Handbook on the Politics of Taxation. Cheltenham: Edward Elgar Publishing.

Schaffer L and Bernauer T (2014) Explaining government choices for promoting renewable energy. Energy Policy, 68, 15-27. doi: 10.1016/j.enpol.2013.12.064

Schaffer LM and Levis A (2021) "Public Discourses on (Sectoral) Energy Policy in Switzerland: Insights from Structural Topic Models”. In Hettich P and Kachi A (eds.), Swiss Energy Governance. Cham: Springer Nature.

Schaffer LM, Oehl B and Bernauer T (2021) "Replication Data for: Are Policy- Makers Responsive to Public Demand in Climate Politics?", Harvard Dataverse, V1, UNF:6: jqdvuAEKmqFZDBHMRFV8qw== [fileUNF]. doi: 10.7910/DVN/WPRN15

Schmidt A, Ivanova A and Schäfer MS (2013) Media attention for climate change around the world: A comparative analysis of newspaper coverage in 27 countries. Global Environmental Change, 23(5): $1233-1248$.

Scruggs L and Benegal S (2013) Social Welfare Generosity and Public Opinion about Climate Change. International Conference of Europeanists. Amsterdam.

Shapiro RY (2011) Public opinion and American democracy. Public Opinion Quarterly, 75(5): 982-1017.

Stadelmann-Steffen I (2011) Citizens as veto players: climate change policy and the constraints of direct democracy. Environmental Politics, 20(4): 485-507. doi: 10.1080/09644016.2011.589577

Stimson JA, Mackuen MB and Erikson RS (1995) Dynamic representation. The American Political Science Review, 89(3): 543-565.

Stokes LC and Breetz HL (2018) Politics in the US energy transition: Case studies of solar, wind, biofuels and electric vehicles policy. Energy Policy, 113, 76-86.

Stoutenborough JW, Bromley-Trujillo R and Vedlitz A (2014) Public support for climate change policy: Consistency in the influence of values and attitudes over time and across specific policy alternatives. Review of Policy Research, 31(6): 555-583.

Sun Y, Pan Z and Shen L (2008) Understanding the Third-Person Perception: Evidence From a MetaAnalysis. Journal of Communication, 58(2): 280-300. doi: 10.1111/j.1460-2466.2008.00385.x

The Guardian (2019) https://www.theguardian.com/environment/2019/may/28/greens-eu-election-mandateleverage-climate-policy (accessed 22 November 2020).

Toshkov D (2015) Exploring the Performance of Multilevel Modeling and Poststratification with Eurobarometer Data. Political Analysis, 23(3): 455-460. doi: 10.1093/pan/mpv009

Tsebelis G (1999) Veto players and law production in parliamentary democracies: An empirical analysis. American Political Science Review, 591-608.

Tsebelis G (2002) Veto players: How political institutions work. Princeton: Princeton University Press.

Tsebelis G (2009) Agenda setting and executive dominance in politics. In Parlamente, Agendasetzung und Vetospieler. Wiesbaden: VS Verlag für Sozialwissenschaften, 13-24. 
Umit R and Schaffer LM (2020) Attitudes towards carbon taxes across Europe: The role of perceived uncertainty and self-interest. Energy Policy, 140, 111385.

United Nations Environment Programme (2020) Emissions Gap Report 2019. UNEP.

Vandeweerdt C, Kerremans B and Cohn A (2016) Climate voting in the US Congress: The power of public concern. Environmental Politics 25(2): 268-288.

Victor DG, House JC and Joy S (2005) A Madisonian approach to climate policy. Science, 309(5742): 1820-1821.

Ward H and Cao X (2012) Domestic and international influences on green taxation. Comparative Political Studies, 45(9): 1075-1103.

Wlezien C (1995) The public as thermostat: Dynamics of preferences for spending. American Journal of Political Science, 39(4): 981-1000.

Wlezien C and Soroka SN (2012) Political Institutions and the Opinion-Policy Link. West European Politics, 35(6): 1407-1432.

Zeit Online (2019) https:/www.zeit.de/politik/deutschland/2019-05/europawahlergebnis-klimapolitikfridays-for-future-protestwahl-gruene (accessed 22 November 2020).

Cite this article: Schaffer LM, Oehl B, and Bernauer T (2022). Are policymakers responsive to public demand in climate politics? Journal of Public Policy 42, 136-164. https://doi.org/10.1017/ S0143814X21000088 